\title{
Population structure and recruitment in mytilid bivalves from the Lucky Strike and Menez Gwen hydrothermal vent fields $\left(37^{\circ} 17^{\prime} \mathrm{N}\right.$ and $37^{\circ} 50^{\prime} \mathrm{N}$ on the Mid-Atlantic Ridge)
}

\author{
Thierry Comtet*, Daniel Desbruyères
}

Laboratoire d'Ecologie Abyssale, DRO-EP, IFREMER Centre de Brest, BP 70, F-29280 Plouzané, France

\begin{abstract}
Population structure and recruitment pattern of undescribed mytilid bivalves that dominate the animal communities associated with vents of the Lucky Strike and Menez Gwen hydrothermal vent fields $\left(37^{\circ} 17^{\prime} \mathrm{N}\right.$ and $37^{\circ} 50^{\prime} \mathrm{N}$ on the Mid-Atlantic Ridge) were studied from size-frequency analyses. Intra-site comparisons reveal that length-frequency distributions differ significantly from one location to the other. This spatial segregation of the sizes could be due to spatio-temporal variability in environmental conditions and to intraspecific competition processes, especially adult-larval interactions (competition for space and food resources, intraspecific larviphagy) that could prevent larvae from settling on surfaces covered by adults. A modal decomposition analysis was conducted after pooling samples collected from different locations at the same site. Polymodal structure of length-frequency distributions indicates that recruitment is likely discontinuous in time. The presence of postlarvae in each population of the Lucky Strike vent field suggests that a recruitment event took place just before sampling in June 1994, and that mytilid recruitment is synchronized between sites, which is confirmed by the comparison of modal values. Length-frequency distribution of the Menez Gwen mytilid population displays similar modal values, especially for the smallest mode. This suggests a synchronization of the recruitment between the 2 vent fields, which are separated by a distance of $60 \mathrm{~km}$. No seasonal pattern in recruitment could be identified although newly recruited individuals were observed in. June 1993 on Lucky Strike sites.
\end{abstract}

KEY WORDS: Hydrothermal vents - Mytilidae - Recruitment Population structure - Size frequency Spatial segregation · Intraspecific competition - Mid-Atlantic Ridge

\section{INTRODUCTION}

The deep-sea hydrothermal ecosystem is characterized by great spatial and temporal instability due to the combination of non-periodic changes related to tectonic events and convection of the heated fluids through the seafloor (Watremez \& Kervevan 1990) and periodic events, some of which correspond to tidal signals (Little et al. 1988, Chevaldonné et al. 1991, Johnson et al. 1994). On fast spreading ridges, such as the East Pacific Rise (EPR) at $13^{\circ} \mathrm{N}$, vent sites appear to

•E-mail: tcomtet@ifremer.fr have a short lifetime (generally no longer than ca $100 \mathrm{yr}$ ) and the locus of hydrothermal activity shifts along the ridge (Lalou et al. 1985, 1993a). On slow spreading ridges, such as the Mid-Atlantic Ridge (MAR), the hydrothermal activity is spatially more focused and stable over the long term, even if the lifetime of an individual vent site is similar to that on the fast spreading ridges (Fouquet et al. 1993, Lalou et al. 1993a, b, Y. Fouquet, J. L. Charlou, J. P. Donval, J. Radford-Knoëry, H. Ondréas et al. unpubl.). Variability in the hydrothermal discharge causes changes in the animal communities associated with vents (Hessler et al. 1985, 1988, Fustec et al. 1987, Jollivet 1993). As a consequence, the vent fauna must adapt to unstable environmental conditions and nutrient supply by rapidly 
colonizing new vents. One might therefore expect vent organisms to display an r-type ecological strategy and large dispersal capabilities (Desbruyères \& Laubier 1983).

The population dynamics of hydrothermal-ventassociated species are poorly known because of the lack of long-term data and the difficulty in gathering the information needed in such studies (i.e. population structure, growth rate, reproductive biology, recruitment, and larval dispersal). A few studies of population structure by means of size-frequency analysis have been conducted on vestimentiferan worms (Siferd 1984, Tunnicliffe 1991, Jollivet 1993), alvinellid polychaetes (McHugh 1989, Jollivet 1993, Zal et al. 1995), serpulid polychaetes and bythograeid crabs (Jollivet 1993), from samples collected at $13^{\circ} \mathrm{N}$ on the EPR and on the Juan de Fuca-Explorer ridge system, which are, respectively, fast and medium spreading ridges (Hékinian et al. 1983, Canadian American Seamount Expedition 1985, Tunnicliffe et al. 1986). These studies give some indication of the dynamics of these species, allowing a better understanding of the processes controlling the evolution and maintenance of the populations. Discontinuous recruitment has been shown to occur most frequently in the hydrothermal invertebrates studied to date, but a continuous pattern has also been documented in some cases. Jollivet (1993) and Zal et al. (1995) hypothesized that recruitment in Alvinella pompejana, Alvinella caudata and Paralvinella grasslei ( 3 alvinellid polychaetes) might occur at least once a year. Moreover, the occurrence of more than one breeding period over a year seems to be confirmed by theoretical calculations for these alvinellid species (Jollivet et al. in press)

Undescribed bivalves belonging to the family Mytilidae dominate the animal communities associated with 2 newly discovered hydrothermal vent fields on the Mid-Atlantic Ridge, Lucky Strike $\left(37^{\circ} 17^{\prime} \mathrm{N}\right)$ and Menez Gwen (37 50' N) (Langmuir et al. 1993, Desbruyères et al. 1994, Fouquet et al. 1995, Van Dover et al, 1996). Morphological and anatomical studies indicated that mytilids from both vent fields belong to a single new species of the genus Bathymodiolus (R. von Cosel, T. Comtet \& E. Krylova unpubl.), distinct from Bathymodiolus puteoserpentis Cosel, Métivier \& Hashimoto, 1994, found at Snake Pit $\left(23^{\circ} \mathrm{N}\right.$ on the MAR), from Bathymodiolus sp. found at the Logatchev vent field $\left(14^{\circ} 45^{\prime} \mathrm{N}\right.$ on the MAR), from the mytilids of the Broken Spur vent field ( $29^{\circ} \mathrm{N}$ on the MAR), from Bathymodiolus thermophilus Kenk \& Wilson, 1985, found from $13^{\circ} \mathrm{N}$ to $22^{\circ} \mathrm{S}$ on the EPR and on the Galapagos Rift, and from 7 other mytilid species inhabiting hydrothermal vents and cold seeps (Craddock et al. 1995). Preliminary results of DNA sequencing for mytilids from Lucky Strike and Menez Gwen confirm that they belong to the same species and differ from B. thermophilus from $13^{\circ} \mathrm{N}$ on the EPR (T. Comtet \& D. Jollivet unpubl data).

The population structure of mytilid bivalves from hydrothermal vents has never been studied in detail, although length-frequency histograms have been published by Rhoads et al. (1982), Smith (1985) and Hessler et al. (1988) for Bathymodiolus thermophilus from the Galapagos Rift vents without any interpretation in terms of population dynamics. Preliminary results on population structure of the mytilid bivalves of Lucky Strike have also been published by Comtet (1994) and Van Dover et al. (1996), from 4 samples collected in June 1993 from 3 sites at Lucky Strike, and suggested a discontinuous recruitment. Their studies asked 3 main questions which the present study will attempt to answer: (1) Is discontinuity in recruitment a general feature of the mytilids from Lucky Strike, i.e. can it be confirmed on the other sites of this vent field? (2) Considering such a discontinuity, is recruitment periodic, and if it is, what is its periodicity? (3) Is recruitment synchronized among the different sites at Lucky Strike and between Lucky Strike and the newly discovered Menez Gwen vent field? We present here the results of the analysis of size-frequency distributions in 6 mytilid bivalve populations sampled in June 1994 during the DIVA 2 cruise at Lucky Strike and Menez Gwen.

\section{MATERIALS AND METHODS}

Study area and sampling. Accurate reference to spatial scales is very important in patchy habitats such as vents. In an attempt to standardize the terms used relative to the spatial scales, we will use the definitions given by Chevaldonné et al. (1997): 'vent' describes a single localized emission of hydrothermal fluid, 'vent site' or 'site' refers to a spatially continuous venting area made of several emissions only a few metres apart, 'vent field' or 'field' refers to a cluster of vent sites located a few 100 s of metres apart, linked by subterranean ducts and which undergo the same temporal variations. Vent fields can be grouped within larger spatial units termed 'venting sectors' or 'venting areas' which correspond to ridge segments.

The Lucky Strike hydrothermal vent field is located at $37^{\circ} 17.5^{\prime} \mathrm{N}, 32^{\circ} 16^{\prime} \mathrm{W}$ on the MAR, in the Azores triple junction area (Fig. 1A) at a depth of ca $1700 \mathrm{~m}$. The active venting area consists of a depression located between 3 volcanic cones (Fig. 1B). The central part of this depression is a lava lake surrounded by several active vent sites (Y. Fouquet et al. unpubl.). The Lucky Strike fauna is dominated by dense mytilid beds that cover surfaces of active sulfide edifices and occur in 

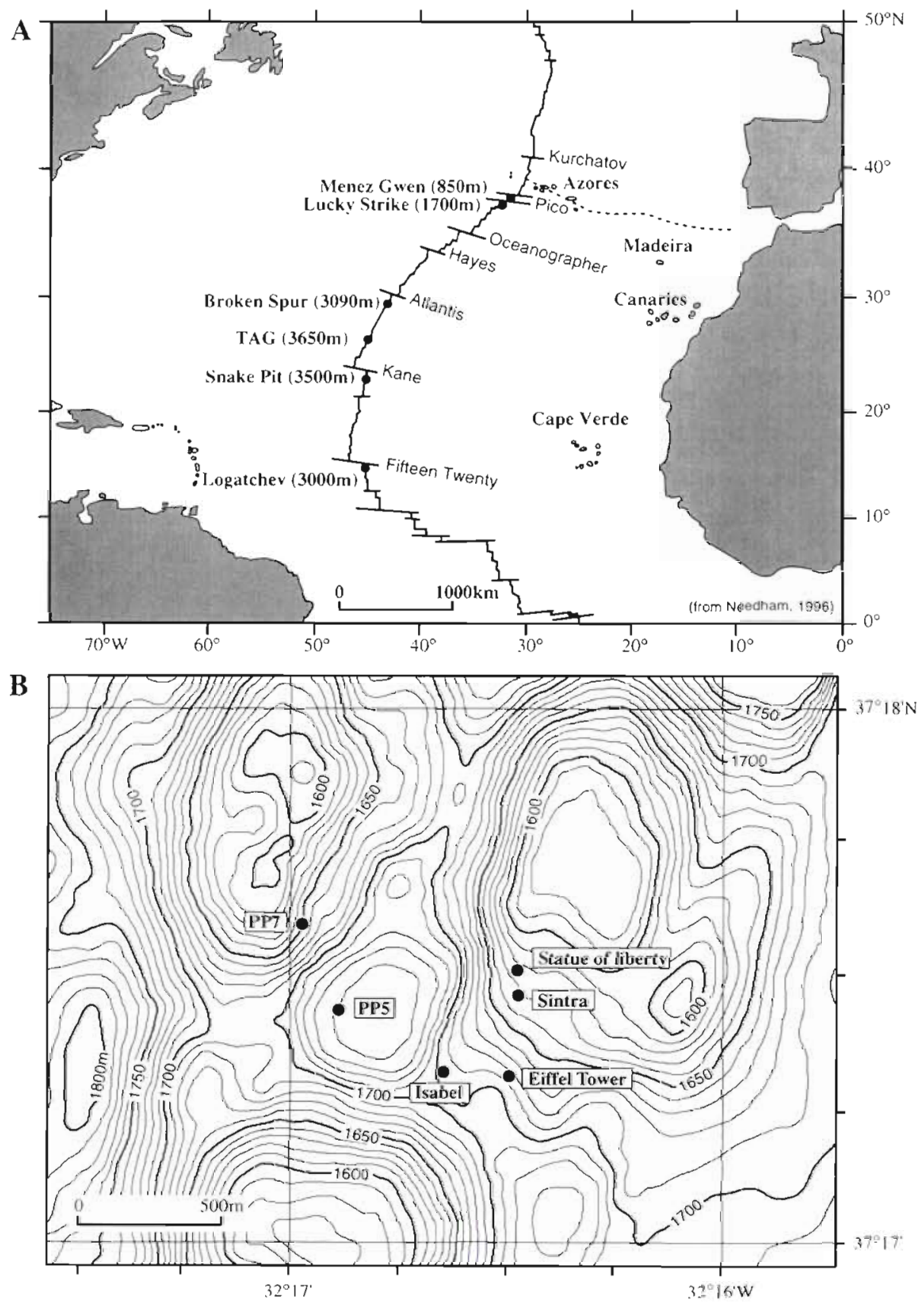

Fig. 1. (A) Locations of the Lucky Strike and Menez Gwen hydrothermal vent fields on the Mid-Atlantic Ridge (MAR). (B) The Lucky Strike hydrothermal vent field, showing locations of the sampling sites. Statue of Liberty was not sampled during the DIVA 2 cruise. Isobaths every $10 \mathrm{~m}$

cracks in the seafloor (Van Dover et al. 1996). The Menez Gwen hydrothermal vent field is located at $37^{\circ} 50^{\prime} \mathrm{N}, 31^{\circ} 31^{\prime} \mathrm{W}$ on the MAR (Fig. 1A), $60 \mathrm{~km}$ north of Lucky Strike, at ca $850 \mathrm{~m}$ depth near the top of a young volcano. The venting site looks very young (10 to 100 yr) but is already very active (Y. Fouquet et al. unpubl.). Scarce clumps of mytilid bivalves dominate the fauna of Menez Gwen (Desbruyères et al. 1994).
Mytilid bivalves were collected during the first leg of the DIVA 2 cruise (D. Desbruyères, chief scientist) in June 1994, using the arm of the French submersible 'Nautile', from 5 sites of the Lucky Strike vent field, PP5 (Pico), PP7 (Bairro Alto), Sintra, Isabel and Eiffel Tower (Fig. 1B), and 1 site at the Menez Gwen vent field (see Table 1). Several samples of mytilids were collected from different locations at a single site, in 
order to avoid a bias that could result from heterogeneity in size distribution, as observed by Comtet (1994), Desbruyères et al. (1994) and Van Dover et al. (1996). Sampling areas were thus selected in situ according to the dominant size of individuals, empirically defined as large or small, and samples of mytilids were collected from both types of locations in order to take all size classes into account. Sampling was done according to 2 criteria: (1) one single sample (composed of several batches collected from a single location) was collected on each dive, (2) mytilids were collected with the sulfide block they occupied to avoid size selection during sampling. After arrival onboard, mytilids and sulfide blocks were fixed with $3 \%$ neutral formalin in seawater, and preserved in $70 \%$ ethanol. In the laboratory, mytilids were sorted from sulfide blocks. Given the large size of the sample collected during Dive 10 ( $\mathrm{n}=10019$ individuals), it was not possible to measure all individuals and stratified subsampling was performed according to Frontier (1983): mytilids were sorted through a series of sieves of decreasing mesh size $(3.15 \mathrm{~mm}, 2 \mathrm{~mm}, 1 \mathrm{~mm}$, $500 \mu \mathrm{m}, 250 \mu \mathrm{m}, 160 \mu \mathrm{m})$; in each size fraction, a proportion of individuals of about $12.5 \%$ was randomly sampled; the actual proportion of each fraction was then calculated and used to extrapolate the results to the total number of individuals. To validate this procedure, the size-frequency distribution of the $3.15 \mathrm{~mm}$ fraction subsample was compared to that of the rest of this fraction, by means of a Kolmogorov-Smirnov 2-sample test (Scherrèr 1984).

Mytilid length (the greatest antero-posterior dimension) was measured with calipers to the nearest $0.01 \mathrm{~mm}$ for individuals more than $5 \mathrm{~mm}$ long (Fig. 2). Individuals between 1 and $5 \mathrm{~mm}$ long were measured under a dissecting microscope (Leica Wild M10) to the nearest $0.01 \mathrm{~mm}$. The smallest individuals (less than $1 \mathrm{~mm}$ long) were measured to the nearest $0.01 \mathrm{~mm}$ using the Mocha 1.2 image analysis software (Jandel Scientific). Fig. 2 shows the dimension measured as length for the smallest individuals. This dimension was chosen to be consistent with the dimension measured for adults. On a subsample of 93 postlarval individuals from Dive 10 , the length of the prodissoconch II was measured to estimate size at settlement (Fig. 2).

Data analysis. Length-frequency histograms were generated with a size-class interval of $3 \mathrm{~mm}$ chosen according to 2 criteria: (1) the main classes (i.e. classes with highest frequencies) should have at least 30 individuals and (2) the number of adjacent empty classes must be minimized (Bhattacharya 1967). Lengthfrequency histograms were then smoothed using a weighted moving average at the third order to rule out spurious peaks (Frontier \& Pichod-Viale 1991, Jollivet 1993, Zal et al. 1995).

Modal decomposition of length-frequency distributions was done using the MIX 2.3 program package (MacDonald \& Green 1986), assuming that mytilid sizes follow a Gaussian distribution within a single cohort. This iterative method, described by MacDonald \& Pitcher (1979), provides the best mathematical fit between a theoretical mixture of normal distributions and the observed one, following the maximum likelihood criteria.

\section{RESULTS}

\section{Validation of Dive 10 subsampling procedure}

To validate the subsampling procedure, the sizefrequency distribution of the $3.15 \mathrm{~mm}$ fraction subsample was compared to that of the rest of the $3.15 \mathrm{~mm}$ fraction by means of the non-parametric KolmogorovSmirnov 2 -sample test. The result $\left(D_{o b s}=0.0926, p=\right.$ 0.1237 ) shows that the frequency distributions in the subsample and in the rest do not differ significantly. The subsampling method therefore did not generate any statistical bias.

\section{Population structure}

Length-frequency histograms were generated from measurements of a total of 8600 mytilids. Mytilid lengths ranged from $0.5 \mathrm{~mm}$, for newly settled individuals attached to sulfide blocks, to $113 \mathrm{~mm}$ for the largest adults (Table 1).

Length-frequency distributions of each sample display a polymodal structure (Fig. 3) and are character- 
ized by a large number of very small individuals $(<1 \mathrm{~cm})$, except that for Dive 13 from Menez Gwen (Fig. 3).

Fig. 4 shows length-frequency distributions for each sampling site after pooling the samples collected on that site. All these distributions show a clear polymodal structure, characterized by a great positive skewness, resulting from the high number of small individuals that dominate the populations of each site except Menez Gwen.

\section{Lucky Strike field}

Intra-site comparisons. Three of the Lucky Strike vent field sites (Isabel, Eiffel Tower and PP7) were sampled more than once. For Isabel, the sizefrequency distributions of Samples 1 and 3 (i.e. the samples taken during Dives 1 and 3, respectively) were significantly different (Kolmogorov-Smirnov test, $\mathrm{p}<0.0001)$. Sample 3 was only composed of small mytilids $(<30 \mathrm{~mm})$, whereas a greater size range was observed in Sample 1, even though it had a smaller sample size (Table 1, Fig. 3). The 2 samples (Dives 6 and 7) collected at PP7 showed a similar size range (Table 1), but their size-frequency distributions were significantly different (Kolmogorov-Smirnov test, $p<0.0001$ ), Sample 7 being composed of a greater proportion of small individuals $(<30 \mathrm{~mm}$ ) (Fig. 3). For Eiffel Tower, Sample 10 was clearly different from Samples 4 and 8 , being exclusively composed of small mytilids (Fig. 3). Comparison between Samples 4 and 8 also indicated a significant difference in their lengthfrequency distributions (Kolmogorov-Smirnov test, $\mathrm{p}<0.0001$ ). Sample 8 showed the largest size-range, with a great proportion of large individuals, whereas
Sample 4 was dominated by individuals of small and medium sizes (Fig. 3). At a finer spatial scale, the length-frequency distributions of 2 mytilid batches collected a few $\mathrm{cm}$ apart on the sulfide block during Dive 2 were clearly different (Fig. 5).

Inter-site comparisons. Length-frequency histograms for each site at the Lucky Strike vent field are given in Fig. 4a-e. These distributions have similar structures, with a great positive skewness due to the abundance of small individuals.

Results of the modal decomposition are given in Table 2. For each distribution, more than 1 well-fitted solution, with 5 to 7 Gaussian components, can be proposed. The main differences between the modal decompositions proposed for a given site consist of the separation of 1 mode into 2, with the other components showing slightly shifted modal values, and are indicated in Fig. 6 by circled areas. For PP7 and Eiffel Tower, the solutions with 6 and 7 modes, respectively, give a better $p$-value for the $\chi^{2}$ goodness-of-fit test. The modal decomposition of the size distribution for Isabel gives 3 solutions with p-values equal to 1 , making discrimination between these solutions difficult. Histograms of the 2 single-sample sites PP5 and Sintra can be decomposed into 6 and 5 components, respectively. For PP5, a solution with 5 modes (PP5 a) is proposed, but in this case the $\chi^{2}$ test may be invalid because of 3 expected frequencies lower than 1 .

\section{Menez Gwen field}

Three samples were collected from the same site of the Menez Gwen vent field. Length-frequency distributions of each sample are given in Fig. 3j-1. Kolmogorov-Smirnov 2-sample tests showed that each size

Table 1. Characteristics of each mytilid bivalve sample collected in June 1994 from the Lucky Strike and Menez Gwen hydrothermal vent fields on the Mid-Atlantic Ridge (MAR). DIX and PP11 are 2 markers placed on a single site at Menez Gwen

\begin{tabular}{|c|c|c|c|c|c|c|c|c|}
\hline & \multirow[t]{2}{*}{ Dive no. } & \multirow[t]{2}{*}{ Date } & \multirow[t]{2}{*}{ Site } & \multirow[t]{2}{*}{ Depth $(\mathrm{m})$} & \multirow[t]{2}{*}{ Sample size } & \multicolumn{3}{|c|}{ Length (mm) } \\
\hline & & & & & & Range & Mean & $\mathrm{SD}$ \\
\hline \multirow[t]{9}{*}{ Lucky Strike } & 01 & Jun 3 & Isabe] & 1685 & 277 & $0.60-112.56$ & 29.55 & 29.77 \\
\hline & 02 & Jun 4 & Sintra & 1622 & 558 & $0.46-83.60$ & 14.84 & 20.11 \\
\hline & 03 & Jun 5 & Isabel & 1685 & 974 & $1.16-26.54$ & 5.52 & 3.65 \\
\hline & 04 & Jun 6 & Eiffel Tower & 1685 & 618 & $1.03-84.12$ & 22.46 & 19.40 \\
\hline & 05 & Jun 7 & PP5 & 1725 & 245 & $0.50-102.86$ & 20.16 & 27.04 \\
\hline & 06 & Jun 8 & PP7 & 1629 & 274 & $0.52-99.81$ & 22.10 & 28.52 \\
\hline & 07 & Jun 9 & PP7 & 1629 & 871 & $0.51-101.66$ & 11.90 & 17.94 \\
\hline & 08 & Jun 10 & Eiffel Tower & 1685 & 321 & $0.81-112.99$ & 49.93 & 31.41 \\
\hline & 10 & Jun 12 & Eiffel Tower & 1685 & 10019 & $0.48-53.73$ & 5.63 & 5.67 \\
\hline \multirow[t]{3}{*}{ Menez Gwen } & 11 & Jun 13 & DIX & 866 & 185 & $0.58-74.54$ & 39.56 & 22.40 \\
\hline & 12 & Jun 14 & PP1 1 & 866 & 144 & $2.75-92.78$ & 57.39 & 25.87 \\
\hline & 13 & Jun 15 & PP11 & 866 & 29 & $62.68-111.56$ & 92.66 & 11.97 \\
\hline
\end{tabular}




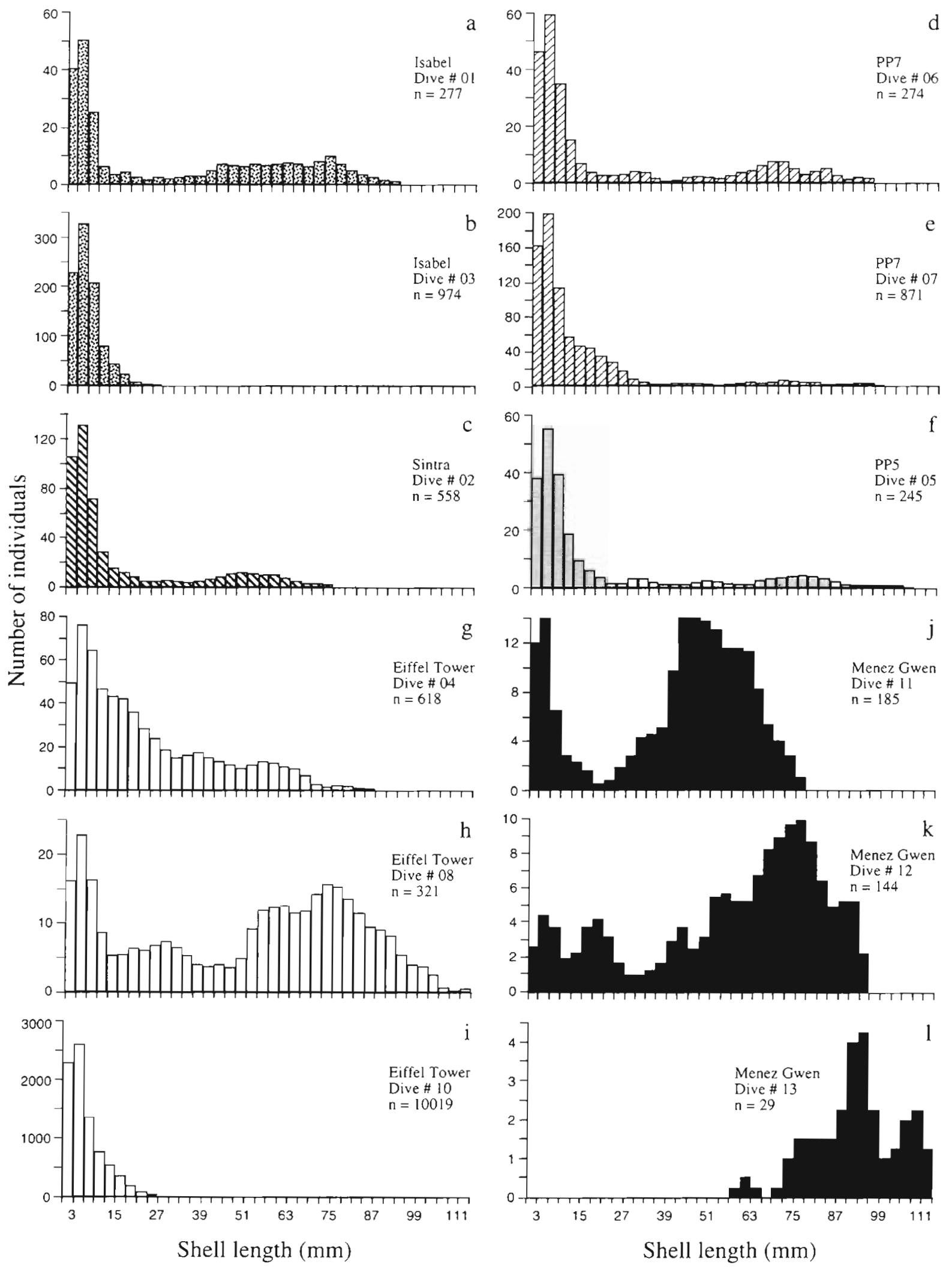

Fig. 3. Shell length frequency histograms of 12 mytilid samples from different dives on the Lucky Strike and Menez Gwen hydrothermal vent fields (MAR). $n$ = sample size 

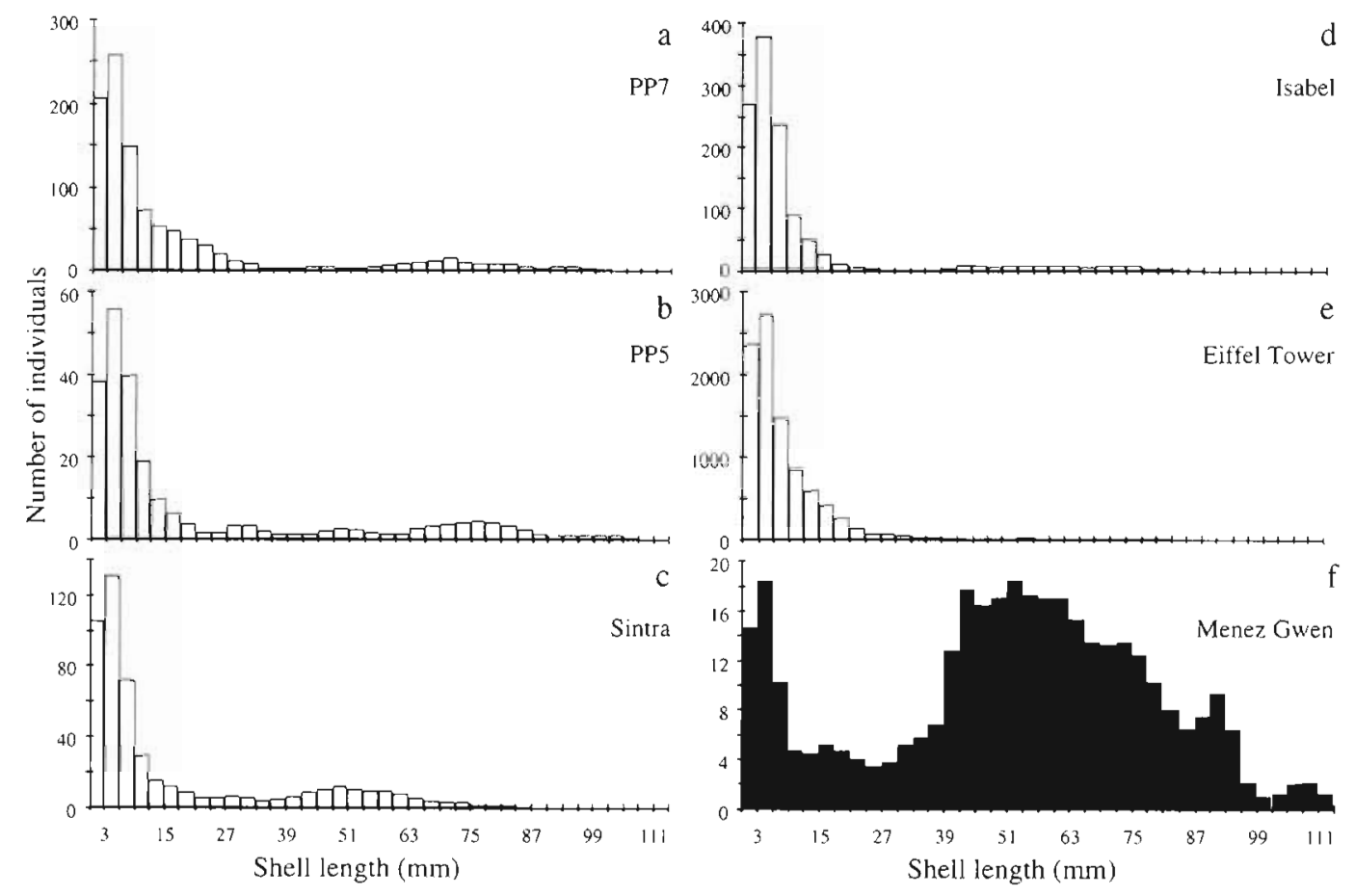

Fig. 4. Shell length frequency histograms of 6 mytilid populations from sampling sites at the Lucky Strike and Menez Gwen hydrothermal vent fields (MAR) obtained by pooling the data from all samples collected from the given site

distribution differed significantly from the 2 others ( $p<0.0001$ for each of the 3 pairwise comparisons). Sample 13 showed a small size range and was exclusively composed of individuals larger than $60 \mathrm{~mm}$ (Table 1). Samples 11 and 12 had a greater size range. Sample 11 was dominated by individuals of medium sizes, whereas Sample 12 was dominated by larger individuals.

Fig. $4 \mathrm{f}$ shows the length-frequency histogram of the mytilid population at Menez Gwen, after pooling of the 3 samples. The population structure at Menez Gwen differs from that at Lucky Strike, in particular by the dominance of individuals of shell length ranging from 40 to $80 \mathrm{~mm}$. Individuals of small sizes were also present, but in lower proportion. The size distribution at Menez Gwen can be decomposed into 6 or 7 modes (Table 3, Fig. 6), both solutions giving a $\chi^{2}$ test $p$-value equal to 1.

\section{Size at settlement}

Size at settlement was estimated by measuring the length of the prodissoconch II (i.e. the larval shell). The mean length of the prodissoconch II, obtained from a subsample of 93 postlarval individuals from Lucky Strike collected during Dive 10 at Eiffel Tower, was $527 \mu \mathrm{m}$ (SD $20 \mu \mathrm{m}$, range 472 to $604 \mu \mathrm{m}$ ).
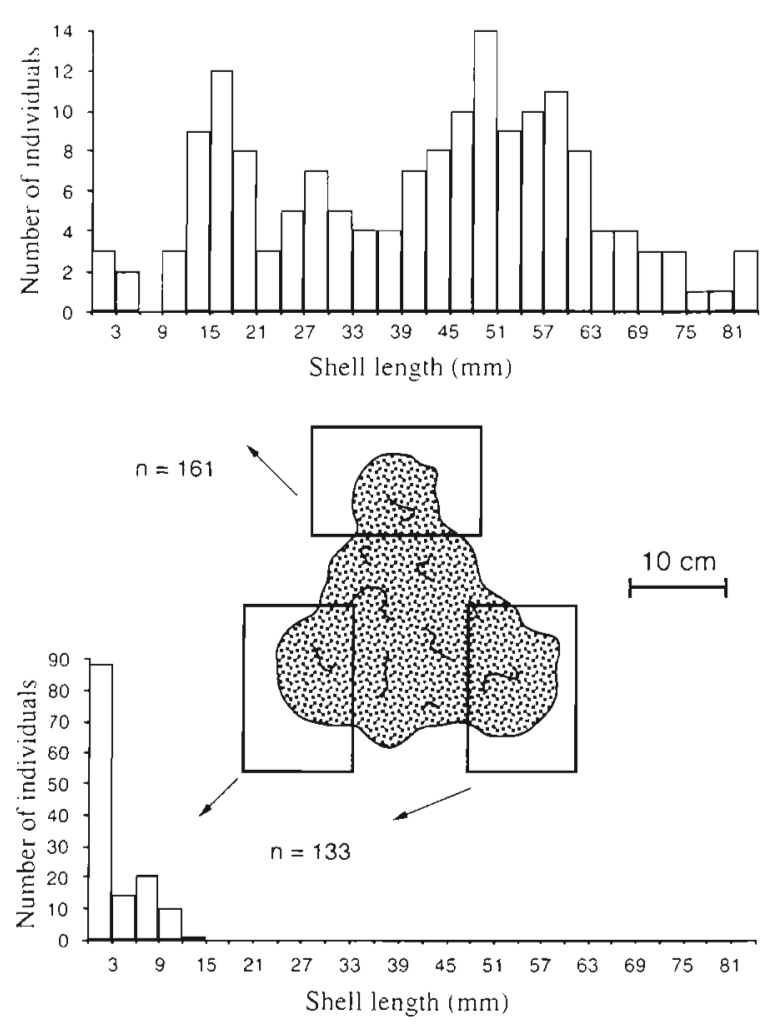

Fig. 5. Shell length frequency histograms for 2 mytilid batches collected on a sulfide block during Dive 2 at Sintra (Lucky Strike hydrothermal vent field). ( $\mathrm{n}=$ batch size) 
Table 2. Modal decomposition of shell length distributions in 5 mytilid bivalve populations from the Lucky Strike hydrothermal vent field, using MTX 2.3. The best solutions (goodness-of-fit $\chi^{2}$ test) obtained after runs with various numbers of modes are presented. More than 1 solution is proposed for each population except Sintra

\begin{tabular}{|c|c|c|c|c|c|c|c|}
\hline Site & 1 & 2 & \multicolumn{4}{|c|}{ Component } & 7 \\
\hline \multicolumn{8}{|c|}{ PP7 a } \\
\hline \multicolumn{8}{|c|}{$\chi^{2}=7.33, p=0.9992, d f=23$} \\
\hline Mode (mm) & 4.26 & 15.45 & 43.38 & 70.42 & 90.18 & & \\
\hline $\mathrm{SD}(\mathrm{mm})$ & 2.90 & 7.17 & 11.73 & 8.17 & 5.82 & & \\
\hline \multicolumn{8}{|l|}{ PP7 b } \\
\hline \multicolumn{8}{|c|}{$\chi^{2}=5.20, p=0.9998, d f=21$} \\
\hline Mode $(\mathrm{mm})$ & 4.18 & 13.74 & 24.22 & 44.38 & 70.07 & 90.36 & \\
\hline $\mathrm{SD}(\mathrm{mm})$ & 2.83 & 5.05 & 4.80 & 8.11 & 8.43 & 5.74 & \\
\hline \multicolumn{8}{|c|}{ Eiffel Tower a } \\
\hline Proportion & 0.37 & 0.23 & 0.13 & 0.11 & 0.12 & 0.04 & \\
\hline Mode (mm) & 4.33 & 13.88 & 32.01 & 57.19 & 74.72 & 91.63 & \\
\hline $\mathrm{SD}(\mathrm{mm})$ & 2.95 & 6.06 & 9.15 & 6.80 & 8.45 & 8.45 & \\
\hline \multicolumn{8}{|l|}{ Eiffel Tower b } \\
\hline Proportion & 0.39 & 0.18 & 0.08 & 0.08 & 0.11 & 0.11 & 0.04 \\
\hline Mode (mm) & 4.35 & 13.56 & 24.13 & 36.74 & 57.15 & 74.77 & 91.42 \\
\hline $\mathrm{SD}(\mathrm{mm})$ & 2.96 & 4.52 & 4.86 & 6.39 & 6.77 & 8.17 & 8.45 \\
\hline \multicolumn{8}{|l|}{ Isabel a } \\
\hline Proportion & 0.75 & 0.14 & 0.02 & 0.04 & 0.05 & & \\
\hline Mode (mm) & 4.43 & 11.88 & 23.67 & 49.36 & 72.64 & & \\
\hline $\mathrm{SD}(\mathrm{mm})$ & 2.76 & 4.13 & 6.93 & 8.92 & 9.18 & & \\
\hline \multicolumn{8}{|c|}{ Isabel b } \\
\hline \multicolumn{8}{|c|}{$\chi^{2}=2.51, p=1.0000, \mathrm{df}=19$} \\
\hline Mode $(\mathrm{mm})$ & 4.34 & 10.62 & 24.24 & 45.07 & 58.26 & 74.18 & \\
\hline $\mathrm{SD}(\mathrm{mm})$ & 2.68 & 4.69 & 6.94 & 6.29 & 7.19 & 8.56 & \\
\hline \multicolumn{8}{|l|}{ Isabel c } \\
\hline \multicolumn{8}{|c|}{$\chi^{2}=1.57, \mathrm{p}=1.0000, \mathrm{df}=17$} \\
\hline Proportion & 0.74 & 0.15 & 0.01 & 0.03 & 0.03 & 0.03 & 0.01 \\
\hline Mode (mm) & 4.42 & 11.79 & 26.92 & 44.49 & 58.49 & 73.61 & 86.38 \\
\hline $\mathrm{SD}(\mathrm{mm})$ & 2.76 & 4.45 & 5.42 & 5.36 & 5.99 & 5.22 & 5.14 \\
\hline \multicolumn{8}{|l|}{ PP5 a } \\
\hline \multicolumn{8}{|c|}{$\begin{array}{l}\chi^{2}=3.74, \mathrm{p}=1.0000, \mathrm{df}=24 \\
\chi^{2} \text { test may be invalid with } 3 \text { ex- } \\
\text { pected frequencies lower than } 1\end{array}$} \\
\hline Proportion & 0.60 & 0.14 & 0.06 & 0.04 & 0.16 & & \\
\hline Mode $(\mathrm{mm})$ & 4.86 & 13.03 & 30.90 & 49.46 & 75.61 & & \\
\hline $\mathrm{SD}(\mathrm{mm})$ & 3.04 & 4.55 & 5.57 & 3.97 & 12.34 & & \\
\hline \multicolumn{8}{|l|}{ PP5 b } \\
\hline \multicolumn{7}{|c|}{$\chi^{2}=2.15, p=1.0000, d f=22$} & \\
\hline Mode $(\mathrm{mm})$ & 4.77 & 12.17 & 30.30 & 51.72 & 74.53 & 94.43 & \\
\hline $\mathrm{SD}(\mathrm{mm})$ & 2.96 & 4.93 & 5.09 & 7.94 & 6.78 & 7.98 & \\
\hline \multicolumn{8}{|l|}{ Sintra } \\
\hline$\chi^{2}=1.61, \mathrm{p}=$ & & & & & & & \\
\hline Proportion & 0.61 & $\begin{array}{r}0.13 \\
1208\end{array}$ & $\begin{array}{r}0.05 \\
27.57\end{array}$ & $\begin{array}{r}0.14 \\
4981\end{array}$ & $\begin{array}{r}0.06 \\
64.89\end{array}$ & & \\
\hline Mode $(\mathrm{mm})$ & $\begin{array}{l}4.12 \\
2.78\end{array}$ & $\begin{array}{r}1.08 \\
4.93\end{array}$ & 6.00 & $\begin{array}{r}49.01 \\
8.18\end{array}$ & $\begin{array}{l}64.89 \\
10.97\end{array}$ & & \\
\hline $\mathrm{SD}(\mathrm{mm})$ & 2.78 & & & & $10.9 t$ & & \\
\hline
\end{tabular}




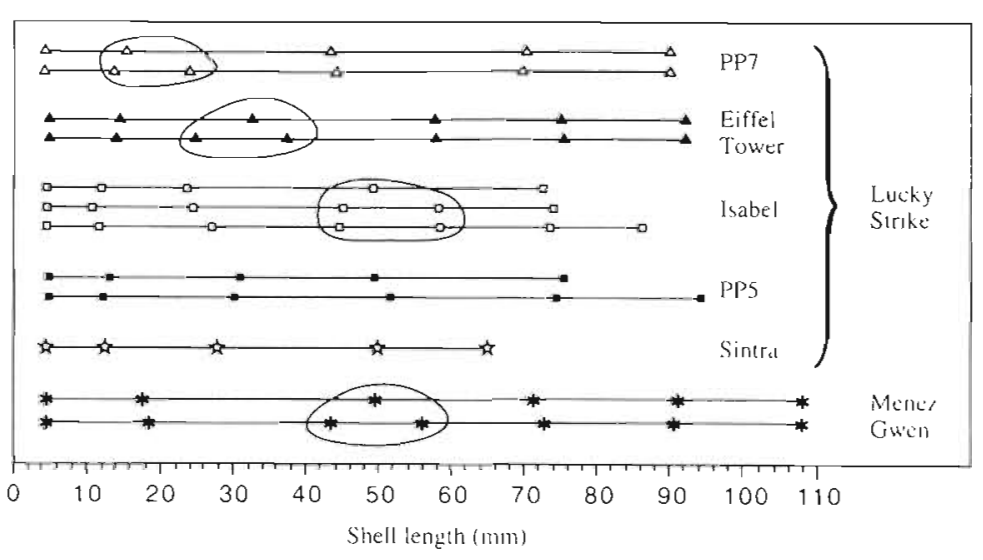

Fig. 6. Summary of the modal decomposition showing the position of each modal value along the shell length axis (see Tables 2 \& 3 for detailed results). The main differences observed between alternative solutions obtained for a given site have been circled

('Alvin' Dives 2604 and 2605, MAR 93 cruise) collected at Statue of Liberty (Lucky Strike, Fig. 1B) seemed to be complementary. The generalization of this phenomenon to other sites of the Lucky Strike and Menez Gwen vent fields shows the importance of the spatial scale in the definition and study of populations of vent mytilids. Populations need to be defined at the scale of a whole vent site in order to take all the size classes into account. Spatial segregation of the sizes also occurs at a finer scale, e.g. on a single sulfide block a few tens of centimetres in size (Fig. 5).

Both in situ and video observations strengthen these findings. Moreover, video observations and time-series temperature measurements revealed a distribution of the sizes (through an empirical distinction between 'large' and 'small') related to the posi-

\section{DISCUSSION}

\section{Intra-site spatial variability of size structure}

On the Lucky Strike vent field, 3 sites were sampled more than once during the series of dives. The sizefrequency distributions in samples collected from different locations at the same site differ in the relative proportions of size classes, although each sample contains small individuals. This is particularly clear considering the different size structures of the 3 samples collected from 3 distinct locations at Eiffel Tower (Fig. $3 g-i$ ). The same phenomenon occurs at Menez Gwen (Fig. 3j-1). These results indicate a spatial segregation of sizes and confirm the preliminary studies of Comtet (1994) and Van Dover et al. (1996) which showed that size distributions of 2 mytilid samples tion of the individuals relative to the fluid sources, the largest individuals living in the warmest areas, with a higher sulfide concentration and lower $\mathrm{pH}$ than areas covered by small mytilids (T. Comtet unpubl. data, P. M. Sarradin, J. C. Caprais, R. Riso, A. Aminot, R. Kerouel \& A. M. Alayse unpubl.). Considering the broad size range observed in our samples (Table 1), it is more likely that the spatial segregation of sizes reflects the spatio-temporal variability in recruitment rather than spatially different growth rates that could occur with respect to the position of the individuals relative to the vents, as reported by Smith (1985) and Fisher et al. (1988) for Bathymodiolus thermophilus from the Galapagos Rift. The spatio-temporal variability of the recruitment could be explained by the spatio-temporal variability in environmental conditions and intraspecific competition, especially through adult-larval interactions.

Table 3. Modal decomposition of shell length distribution in a mytilid bivalve population from the Menez Gwen hydrothermal vent field, using MIX 2.3. Two solutions are presented

\begin{tabular}{|c|c|c|c|c|c|c|c|}
\hline \multirow[t]{2}{*}{ Site } & \multicolumn{7}{|c|}{ Component } \\
\hline & 1 & 2 & 3 & 4 & 5 & 6 & 7 \\
\hline \multicolumn{8}{|l|}{ Menez Gwen a } \\
\hline \multicolumn{8}{|c|}{$\chi^{2}=3.17, p=1.0000, d f=25$} \\
\hline Mode $(\mathrm{mm})$ & 4.15 & 17.49 & 49.43 & 71.59 & 91.00 & 107.95 & \\
\hline $\mathrm{SD}(\mathrm{mm})$ & 2.75 & 7.05 & 9.99 & 8.81 & 4.24 & 3.48 & \\
\hline \multicolumn{8}{|l|}{ Menez Gwen b } \\
\hline \multicolumn{8}{|c|}{$\chi^{2}=3.32, p=1.0000, \mathrm{df}=23$} \\
\hline Proportion & 0.12 & 0.09 & 0.20 & 0.24 & 0.23 & 0.10 & 0.02 \\
\hline Mode (mm) & 4.16 & 18.20 & 43.40 & 56.07 & 72.62 & 90.45 & 108.17 \\
\hline $\mathrm{SD}(\mathrm{mm})$ & 2.77 & 7.56 & 7.19 & 7.18 & 7.28 & 4.78 & 3.27 \\
\hline
\end{tabular}


Variability of the hydrothermal activity

The hydrothermal activity is characterized by a great spatial and temporal variability. Despite the difficulty in distinguishing spatial and temporal effects, the spatial variability of the hydrothermal discharge is known to influence the spatial structure and distribution of the megafauna associated with vents. The steep physicochemical gradients create various micro-environments in which the different species live with respect to their ecological affinities (Desbruyères et al. 1982, Fustec et al. 1987, Fisher et al. 1988, Hessler et al. 1988, Jollivet 1993). At the Lucky Strike sites, the spatial variability, mainly produced by different types of fluid emissions, i.e. low-temperature diffusing fluids, high-temperature fluids expulsed through black smoker chimneys or trapped by flanges, provides micro-habitats that are more or less suitable for the settlement of young mytilids. Spatial heterogeneity of bottom currents and substratum characteristics (e.g. presence or absence of irregularities or crevices) could also play a role since hydrothermal vent mytilids have planktonic larvae (Lutz et al. 1980). In addition, the temporal variability of the hydrothermal discharge (e.g. fluctuations of intensity, displacement of the activity) probably affects settlement at a given location by changing the suitability of the micro-habitats between successive recruitment events. At Menez Gwen, the spatial segregation of the sizes was more accentuated, with Sample 13 containing no small individuals. However, the small size of this sample necessitates some caution in making interpretations. In this case, spatial heterogeneity in the nature of the substratum could play an important role, since the major part of the site is covered by soft substratum made of barite (Y. Fouquet et al. unpubl.) that is less suitable for settlement than hard structures.

\section{Intraspecific interactions}

Johnson et al. (1994) showed that dense mytilid clumps laterally disperse the vent fluids, and suggested that this process could interfere with the settlement of other hydrothermal vent organisms. Such a process could also influence the settlement of the offspring of adults in the clumps, by driving settling individuals to the periphery of the bed. At Lucky Strike, one might suppose that such interactions could occur, since mytilids reach high densities (up to 10000 ind. $\mathrm{m}^{-2}$; A. Colaço pers. comm.)

Lucky Strike mytilids might compete for both space and nutrient resources. Since hydrothermal mytilid larvae live in the plankton, intraspecific competition for food is probably weak between adults and larvae. This process, if it exists, is therefore more likely to occur at the time of settlement and between adults and postlarvae, and could affect the survival of the postlarvae. Mytilids of Lucky Strike and Menez Gwen feed mainly on both methanotrophic and sulfide-oxidizing endosymbiotic intracellular bacteria which are located in their gills (Fiala-Médioni et al. 1996). Therefore, the reduction by adults of the sulfide concentration in the venting fluid as it passes through their aggregations (Johnson et al. 1994) could prevent larvae from settling in adult clumps, or reduce the survival of newly recruited individuals.

Mytilids associated with hydrothermal vents can feed on particulate material (Le Pennec et al. 1990, Page et al. 1991), in which could be included their own larvae. This has been observed in the mytilids from the Logatchev vent field $\left(14^{\circ} 45^{\prime} \mathrm{N} / \mathrm{MAR}\right)$, for which juvenile specimens have been found in the stomachs of adults (R. von Cosel et al. unpubl.). Such an intraspecific larviphagy (cannibalism) is known to significantly influence the population dynamics of shallow-water and freshwater filter-feeding bivalves and is considered a regulating mechanism of the population size, providing a negative relationship between recruitment success and adult densities (Timko 1979, André \& Rosenberg 1991, Bachelet et al. 1992, André et al, 1993). For the Lucky Strike mytilids, this process, if it exists, does not totally prevent larvae from settling in adult beds, since juveniles have been observed on the shells of living adults (Van Dover et al. 1996) and since very small individuals were obtained in every sample (Fig. 3). This could be related to the fact that reduction of larval settlement at the scale of a single adult may be small or moderate, i.e. larvae can settle in the vicinity of adults by escaping the inhalant current, but may be significant at the scale of a population (Ertman \& Jumars 1988, André et al. 1993).

\section{Recruitment pattern of the Lucky Strike and Menez Gwen mytilids}

Due to the spatial heterogeneity of the size structure within a single site, study of recruitment pattern was conducted after pooling the samples collected from different locations of the same site. Modal decomposition of the length-frequency histograms of each site (Fig. 4, Tables $2 \& 3$ ) shows that each distribution can be considered as a mixture of 5 to 7 Gaussian components assumed to represent successive cohorts. It is necessary to be cautious when using the term cohort, which should be associated with a birth date, since to date no method of age determination exists for hydrothermal vent mytilids. More than one solution is proposed for each distribution, both in terms of number and location of the modes, due to the limits of the method we used. 
MacDonald (1987) and Le Guen \& Morizur (1989) noted that the choice between the different decompositions obtained through the MIX method (MacDonald \& Pitcher 1979) is difficult without prior knowledge about the biology of the species. However, Gage (1995) indicated that this type of method, based on non-linear optimization procedures, offers a more powerful and less subjective approach than the graphical ones (Harding 1949, Cassie 1954, Bhattacharya 1967) when overlapping of modes is low. In our study, we graphically rejected the solutions in which overlapping between successive modes was too great.

Polymodality of size distributions indicates that mytilid recruitment is discontinuous in time, as has been hypothesized for the majority of hydrothermal vent species studied to date (Table 4). Furthermore, the size distributions of the 5 Lucky Strike populations (Fig. $4 \mathrm{a}-\mathrm{e}$ ) show similar structures characterized by a peak of small individuals with a modal value of ca $4.5 \mathrm{~mm}$ (range 4.18 to $4.86 \mathrm{~mm}$ ) and a high proportion (Table 2), above $50 \%$ for PP7, Isabel, PP5 and Sintra, and near $40 \%$ for Eiffel Tower. Such an occurrence of postlarval and juvenile stages at each Lucky Strike site suggests that a massive recruitment event took place just before sampling in June 1994 and that this event was synchronized between sites (inter-site distances range from 200 to $1000 \mathrm{~m}$ ). The position of the next modes depends on the individual growth rates. The lack of growth data for Lucky Strike mytilids makes any inference on the recruitment synchrony for the modes other than the first one tentative, and makes the use of statistical methods to test it invalid. Even if successive recruitment events are synchronized, the position of corresponding modes along the length axis could be statistically different due to growth variability between vent sites. Therefore, a statistical difference between mode values will not necessarily imply a lack of synchrony. However, some modal values are consistently encountered in the distributions (Fig. 6, Table 2): modes near $13 \mathrm{~mm}$ (range 10.62 to $15.45 \mathrm{~mm}$ ), $72 \mathrm{~mm}$ (range 70.07 to $75.61 \mathrm{~mm}$ ) and $90 \mathrm{~mm}$ (range 86.38 to $94.43 \mathrm{~mm}$ ) are present in every sample except Sintra. The middle of the distributions is more difficult to decompose, as illustrated by the 3 circled areas represented in Fig. 6 for Lucky Strike. If we consider only the sites sampled several times (PP7, Eiffel Tower and Isabel), 3 other modes seem to be present at ca 25, 45 and $57 \mathrm{~mm}$ (Table 2), but not at every site. Recruitment thus may not occur (at least with the same intensity) at all sites of the Lucky Strike vent field even if it is synchronized over the whole field (as is hypothesized in regard to the first mode).

The pronounced positive skewness observed in each distribution might imply either a high mortality in the early post-settlement stages, if we assume that each recruitment event is of the same amplitude, or a high variability in the number of recruits. Mortality could be explained by the intraspecific competition discussed above and predation by fishes, the bythograeid crab Segonzacia mesatlantica and the undescribed conid gastropod Phymorhynchus sp.

Table 4. List of hydrothermal-vent-associated species for which recruitment pattern has been inferred from size-structure analysis. JdF: Juan de Fuca; Ax: Axial Seamount; EPR: East Pacific Rise $\left(13^{\circ} \mathrm{N}\right)$; Gal: Galapagos Rift; LS-MG: Lucky StrikeMenez Gwen

\begin{tabular}{|c|c|c|c|}
\hline Species & Localization & Recruitment pattern & Source \\
\hline \multicolumn{4}{|l|}{ Vestimentiferan worms } \\
\hline \multirow[t]{2}{*}{ Ridgeia piscesae } & Taylor vent (JdF, Ax) & Possibly continuous? & Siferd (1984), Tunnicliffe (1991) \\
\hline & Shepherd vent $(\mathrm{JdF}, \mathrm{Ax})$ & Discontinuous & Siferd (1984) \\
\hline Tevnia jerichonana & EPR & Discontinuous & Jollivet (1993) \\
\hline Oasisia spp. & EPR & Discontinuous & Jollivet (1993) \\
\hline Riftia pachyptila & EPR & Discontinuous & Jollivet (1993) \\
\hline \multicolumn{4}{|l|}{ Alvinellid polychaete worms } \\
\hline Paralvinella pandorae pandorae & Explorer (JdF) & Continuous or semi-continuous & McHugh (1989) \\
\hline Paralvinella palmiformis & Explorer (JdF) & $\begin{array}{l}\text { Discontinuous (symchronized } \\
\text { oogenesis) }\end{array}$ & McHugh (1989) \\
\hline Paralvinella pandorae irlandei & EPR & Discontinuous & Jollivet (1993) \\
\hline Paralvinella grasslei & EPR & Discontinuous (synchronized) & Jollivet (1993), Zal et al. (1995) \\
\hline Alvinella pompejana & EPR & Discontinuous & Jollivet (1993) \\
\hline Alvinella caudata & EPR & Discontinuous & Jollivet (1993) \\
\hline \multicolumn{4}{|l|}{ Serpulid polychaete worms } \\
\hline Protis hydrothermica & EPR & Discontinuous & Jollivet (1993) \\
\hline \multicolumn{4}{|l|}{ Mytilid bivalves } \\
\hline Undescribed species & LS-MG & Discontinuous (synchronized) & $\begin{array}{l}\text { Comtet (1994), Van Dover et al } \\
\text { (1996), present study }\end{array}$ \\
\hline
\end{tabular}


Size distribution of the Menez Gwen population (Fig. 4f) shows a different structure characterized by the dominance of individuals of shell length ranging between 40 and $80 \mathrm{~mm}$. However, modal decomposition reveals that modal values are close to those obtained for the Lucky Strike populations, especially the mode at $4.16 \mathrm{~mm}$ (Table 3), indicating a recruitment event just before sampling in June 1994. The small size of the recruitment peak could indicate a small number of recruits produced during the last event. We cannot exclude a sampling bias, since the spatial distribution of the Menez Gwen mytilids is more scarce than at Lucky Strike, thus requiring a more extensive sampling. Despite its small size, the recruitment peak is clearly distinct and suggests that recruitment is synchronized between Menez Gwen and Lucky Strike (60 km apart).

It is noteworthy that newly recruited mytilids were observed at Statue of Liberty (Lucky Strike) in June 1993 (Comtet 1994, Van Dover et al. 1996), i.e. 1 yr before sampling for this study. However, the lack of data from other times of the year does not allow us to draw any conclusion about the potential seasonality of the recruitment

Acknowledgements. We gratefully acknowledge the captain and crew of the NO 'Nadir', the pilots and team of the submersible 'Nautile', A.-M. Alayse, co-chief-scientist (with D.D.) of the DIVA 2 cruise, and all the participants of the first leg of the DIVA 2 cruise for their help in collecting samples. We are indebted to P. Briand (CENTOB, IFREMER) for help in sorting samples. We also thank $P$. Chevaldonné, N. Cosson, D. Jollivet, P.-M. Sarradin, M. Segonzac, and M. Sibuet for their helpful comments on this manuscript. We thank V. Martin for drawings and illustrations. This work was supported by the European Community (MAST3-CT95-0040 AMORES), IFREMER, and the Ministère de l'Education Nationale de l'Enseignement Supérieur et de la Recherche

\section{LITERATURE CITED}

André C, Jonsson PR, Lindegarth M (1993) Predation on settling bivalve larvae by benthic suspension feeders: the role of hydrodynamics and larval behaviour. Mar Ecol Prog Ser 97:183-192

André C, Rosenberg R (1991) Adult-larval interactions in the suspension-feeding bivalves Cerastoderma edule and Mya arenaria. Mar Ecol Prog Ser 71:227-234

Bachelet G, Desprez M, Ducrotoy JP, Guillou J, Labourg PJ, Rybarczyk H, Sauriau PG, Elkaim B, Glémarec M (1992) Rôle de la compétition intraspécifique dans la régulation du recrutement chez la coque, Cerastoderma edule (L.) Ann Inst Océanogr 68:75-87

Bhattacharya CG (1967) A simple method of resolution of a distribution into gaussian components. Biometrics 23 $115-135$

Canadian American Seamount Expedition (1985) Hydrothermal vents on an axis seamount of the Juan de Fuca ridge. Nature 313:212-214
Cassie RM (1954) Some uses of probability paper in the analysis of size frequency distributions. Aust J Mar Freshwat Res 3:513-522

Chevaldonné $P$, Desbruyères $D$, Le Haître $M$ (1991) Timeseries of temperature from three deep-sea hydrothermal vent sites. Deep Sea Res 38:1417-1430

Chevaldonné $P$, Jollivet $D$, Vangriesheim $A$, Desbruyères $D$ (1997) Hydrothermal-vent alvinellid polychaete dispersal in the eastern Pacific. 1. Influence of vent site distribution, bottom currents and biological patterns. Limnol Oceanogr $42: 67-80$

Comtet I (1994) Etude de la croissance allométrique et de la structure des populations de modioles sur la zone hydrothermale Lucky Strike $\left(37^{\circ} 17^{\prime} \mathrm{N}\right.$ sur la ride médioatlantique). DEA d'Océanologie Biologique, Université de Bretagne Occidentale, Brest

Craddock C, Hoeh WR, Gustafson RG, Lutz RA, Hashimoto J, Vrijenhoek RJ (1995) Evolutionary relationships among deep-sea mytilids (Bivalvia: Mytilidae) from hydrothermal vents and cold-water methane/sulfide seeps. Mar Biol 121: $477-485$

Desbruyères $D$, Alayse AM, Antoine $E$, Barbier $G$, Barriga $F_{1}$ Biscoito M, Briand P, Brulport JP, Comtet $T$, Cornec L, Crassous P, Dando P, Fabri MC, Felbeck H, Lallier F, FialaMédioni A, Gonçalves J, Ménard F, Kerdoncuff J, Patching J, Saldanha L, Sarradin PM (1994) New information on the ecology of deep-sea vent communities in the Azores Triple Junction area: preliminary results of the Diva 2 cruise (May 31-July 4, 1994). InterRidge News 3:18-19

Desbruyères D, Crassous $P$, Grassle $J$, Khripounoff $A$, Reyss D, Rio M, Van Praet M (1982) Données écologiques sur un nouveau site d'hydrothermalisme actif de la ride du Pacifique oriental. CR Acad Sci Paris Ser III 295:489-494

Desbruyères D, Laubier L (1983) Primary consumers from hydrothermal vent animal communities. In: Rona PA, Boström K, Laubier L, Smith KL Jr (eds) Hydrothermal processes at seafloor spreading centers. Plenum Press, New York, p 711-734

Ertman SC, Jumars PA (1988) Effects of bivalve siphonal currents on the settlement of inert particles and larvae. J Mar Res 46:797-813

Fiala-Médioni A, Cavanaugh C, Dando P, Van Dover CL (1996) Symbiotic mussels from the Mid-Atlantic Ridge: adaptations to trophic resources. J Conf Abs 1:788

Fisher CR, Childress JJ, Arp AJ, Brooks JM, Distel D, Favuzzi JA, Felbeck H, Hessler R, Johnson KS, Kennicutt MC II, Macko SA, Newton A. Powell MA, Somero GN, Soto T (1988) Microhabitat variation in the hydrothermal vent mussel, Bathymodiolus thermophilus, at the Rose Garden vent on the Galapagos Rift. Deep Sea Res 35:1769-1791

Fouquet $Y$, Ondréas $H$, Charlou JL, Donval JP, RadfordKnoery J, Costa I, Lourenço N, Tivey MK (1995) Atlantic lava lakes and hot vents. Nature 377:201

Fouquet Y, Wafik A, Cambon P, Mével C, Meyer G, Gente P (1993) Tectonic setting and mineralogical and geochemical zonation in the Snake Pit sulfide deposit (Mid-Atlantic Ridge at $23^{\circ} \mathrm{N}$ ). Econ Geol 88:2018-2036

Frontier S (1983) Choix et contraintes de l'échantillonnage écologique. In: Frontier S (ed) Stratégies d'échantillonnage en écologie. Masson, Paris, p 15-62

Frontier S, Pichod-Viale D (1991) Ecosystèmes: structure, fonctionnement, évolution. Masson, Paris

Fustec $A$, Desbruyères $D$, Juniper SK (1987) Deep-sea hydrothermal vent communities at $13^{\circ} \mathrm{N}$ on the East Pacific Rise: microdistribution and temporal variations Biol Oceanogr 4:121-164

Gage JD (1995) Demographic modelling in the analysis of 
population dynamics of deep-sea macrobenthos. Int Rev Gesamten Hydrobiol 80:171-185

Harding JP (1949) The use of probability paper for the graphical analysis of polymodal frequency distributions. J Mar Biol Assoc UK 28:141-153

Hékinian R, Février $M$, Avedik $F$, Cambon $P$, Charlou JL, Needham HD, Raillard J, Boulègue J, Merlivat L, Moinet A, Manganini S, Lange J (1983) East Pacific Rise near $13^{\circ} \mathrm{N}$ : geology of new hydrothermal fields. Science 219 : $1321-1324$

Hessler RR, Smithey WM, Boudrias MA, Keller CH, Lutz RA, Childress JJ (1988) Temporal change in megafauna at the Rose Garden hydrothermal vent (Galapagos Rift; eastern tropical Pacific). Deep Sea Res 35:1681-1709

Hessler RR, Smithey WM, Keller CH (1985) Spatial and temporal variation of giant clams, tube worms and mussels at deep-sea hydrothermal vents. Bull Biol Soc Wash 6: 411-428

Johnson KS, Childress JJ, Beehler CL, Sakamoto CM (1994) Biogeochemistry of hydrothermal vent mussel communities: the deep-sea analogue to the intertidal zone. Deep Sea Res 41:993-1011

Jollivet D (1993) Distribution et évolution de la faune associée aux sources hydrothermales profondes à $13^{\circ} \mathrm{N}$ sur la dorsale du Pacifique oriental: le cas particulier des polychètes Alvinellidae. Thèse de Doctorat, Université de Bretagne Occidentale, Brest

Jollivet D, Dixon LRJ, Desbruyères D, Dixon DR (in press) Ribosomal (IDNA) variation in a deep-sea hydrothermal vent polychaete, Alvinella pompejana Desbruyères and Laubier, from $13^{\circ} \mathrm{N}$ on the East Pacific Rise. J Mar Biol Assoc UK

Lalou C, Brichet E, Hékinian R (1985) Age dating of sulfide deposits from dxidl and off-axial structures on the East Pacific Rise near $12^{\circ} 50^{\prime} N$. Earth Planet Sci Lett 75:59-71

Lalou C, Reyss JL, Brichet E (1993a) Actinide-series disequilibrium as a tool to establish the chronology of deep-sea hydrothermal activity. Geochim Cosmochim Acta 57: $1221-1231$

Lalou C, Reyss JL, Brichet E, Arnold M, Thompson G, Fouquet Y, Rona PA (1993b) New age data for Mid-Atlantic Ridge hydrothermal sites: TAG and Snakepit chronology revisited. J Geophys Res B 98:9705-9713

Langmuir $\mathrm{CH}$, Fornari D, Colodner D, Charlou JL, Costa I, Desbruyères D, Desonie $D$, Emerson $T$, Fiala-Médioni $A$, Fouquet $Y$, Humphris S, Saldanha L, Sours-Page R, Thatcher M, Tivey M, Van Dover CL, Von Damm K, Wiese K, Wilson C (1993) Geological setting and characteristics of the Lucky Strike vent field at $37^{\circ} 17^{\prime} \mathrm{N}$ on the MidAtlantic Ridge. EOS Trans Am Geophys Union 74:99

Le Guen JC, Morizur Y (1989) Comparaison de méthodes de décomposition de distributions polymodales de fréquences de longueurs en distributions unimodales successives (NORMSEP - MIX - maximums successifs), application aux 'Bossus' (Pseudotolithus elongatus) du Congo. Publ Dép Halieut Ecole Natl Supér Agron Rennes 11:1-29

Le Pennec M, Donval A, Herry A (1990) Nutritional strategies of the hydrothermal ecosystem bivalves. Prog Oceanogr 24:71-80

Little SA, Stolzenbach KD, Grassle FJ (1988) Tidal current effects on temperature in diffuse hydrothermal flow

Editorial responsibility: Otto Kinne (Editor),

Oldendorf/Luhe, Germany
Guaymas Basin. Geophys Res Lett 15:1491-1494

Lutz RA, Jablonski D, Rhoads DC, Turner RD (1980) Larval dispersal of a deep-sea hydrothermal vent bivalve from the Galapagos Rift. Mar Biol 57:127-133

MacDonald PDM (1987) Analysis of length-frequency distributions. In: Summerfelt RC, Hall GE (eds) Age and growth of fish. Iowa State University Press, Ames, p 371-384

MacDonald PDM, Green PEJ (1986) User's guide to program MIX: an interactive program for fitting mixtures of distributions. Technical notes. Ichthus Data Systems, Hamilton, ON

MacDonald PDM, Pitcher TJ (1979) Age-groups from size-frequency data: a versatile and efficient method of analysing distribution mixtures. J Fish Res Board Can 36:987-1001

McHugh D (1989) Population structure and reproductive biology of two sympatric hydrothermal vent polychaetes, Paralvinella pandorae and P. palmiformis. Mar Biol 103 95-106

Needham HD (1996) Some features of the North AmericaAfrica plate boundary. J Conf Abs 1:834-835

Page HM, Fiala-Médioni A, Fisher CR, Childress JJ (1991) Experimental evidence for filter-feeding by the hydrothermal vent mussel, Bathymodiolus thermophilus. Deep Sea Res 38:1455-1461

Rhoads DC, Lutz RA, Cerrato RM, Revelas EC (1982) Growth and predation activity at deep-sea hydrothermal vents along the Galapagos Rift. J Mar Res 40:503-516

Scherrer B (1984) Biostatistique. Gaëtan Morin éditeur. Chicoutimi, QC

Siferd TD (1984) Juan de Fuca pogonophorans: morphology and population characteristics of the hydrothermal vent beardworm. BSc research project report, University of Victoria, BC

Smith KL Jr (1985) Deep-sea hydrothermal vent mussels: nutritional state and distribution at the Galapagos Rift. Ecology 66:1067-1080

Timko P (1979) Larviphagy and oophagy in benthic invertebrates: a demonstration for Dendraster excentricus (Echinoidea). In: Stancyk SE (ed) Reproductive ecology of marine invertebrates. University of South Carolina Press, Columbia, p 91-98

Tunnicliffe $\mathrm{V}$ (1991) The biology of hydrothermal vents: ecology and evolution. Oceanogr Mar Biol Annu Rev 29: 319-407

Tunnicliffe V, Botros M, de Burgh ME, Dinet A, Johnson HP, Juniper SK, McDuff RE (1986) Hydrothermal vents of Explorer Ridge, northeast Pacific. Deep Sea Res 33: 401-412

Van Dover CL, Desbruyères $D$, Segonzac $M$, Comtet $T$, Saldanha L, Fiala-Médioni A, Langmuir C (1996) Biology of the Lucky Strike hydrothermal field. Deep Sea Res I 43: $1509-1529$

Watremez P, Kervevan C (1990) Origine des variations de l'activité hydrothermale: premiers éléments de réponse d'un modèle numérique simple. CR Acad Sci Paris Ser II 311:153-158

Zal F, Jollivet D, Chevaldonné P, Desbruyères D (1995) Reproductive biology and population structure of the deep-sea hydrothermal vent worm Paralvinella grasslei (Polychaeta: Alvinellidae) at $13^{\circ} \mathrm{N}$ on the East Pacific Rise. Mar Biol 122:637-648

Submitted: May 6, 1997; Accepted: December 10, 1997

Proofs received from author(s): February 23, 1998 